\title{
ASPECTS OF KIDNEYS MORPHOMETRY
}

\section{Bucur Alina Ana-Maria1, Bordei Petru', Ispas Viorel'1}

${ }^{1}$ University "Ovidius" of Constanţa, Faculty of Medicine

\begin{abstract}
Our results were obtained by examining subjects without renal pathology, aged 26-83 on a General Electric - Voluson 730 Expert ultrasound. The left kidney length was found between 56.98-122.90 mm, for female being 56.98-110.60 $\mathrm{mm}$, and for male $84.73-122.90 \mathrm{~mm}$. The length of the right kidney was between 55.50-125.0 mm, for female being 55.50-108.40 mm, and for male 62.04-125.0 mm. The width of the left kidney in the renal hillum was found to be between 15.54-41.10 mm, for female being between 15.54-31.0 $\mathrm{mm}$, and for male between 16.19-41.10 $\mathrm{mm}$. The thickness of the left kidney in the renal hillum was found to be between 40.0-75.80 mm, with the female being 44.02-71.02 $\mathrm{mm}$, and the male between 40.0-75.80 $\mathrm{mm}$. The right kidney thickness in the renal hillum was found to be between 41.67-82.36 $\mathrm{mm}$, for female being between 41.67-60.27 $\mathrm{mm}$ and for male 43.89-82.36 $\mathrm{mm}$.
\end{abstract}

Keywords: right / left kidney - morphometry

\section{Introduction}

The kidneys are located on the posterior abdominal wall, right and left to the vertebral column, being retroperitoneal organs $(1,2)$ from thoracic vertebra T11 and L1-L2 intervertebral disc (3) or thoracic vertebrae T11-T12 and lumbar vertebrae L1 -L2 $(1,2)$. The large axle of each kidney is not exactly vertical, but slightly inclined cranio-caudal and medio-lateral, so that their upper extremities are closer and are also not disposed in the frontal plane, the anterior surface being oriented laterally and the posterior surface being oriented medial (1). To male weighs $140 \mathrm{~g}$, $(1,3)$, and $125 \mathrm{~g}$ to female $(1,3)$. After $(2)$ weighs
130-140 g, with the left kidney sometimes thicker. The dimensions of the kidney are slightly lower in female than male (2).

\section{Materials and method}

Our study was conducted on adult patients who did not have kidney problems aged 26-83 on a General Electric ultrasound - Voluson 730 Expert. The length (height) of the kidney between the two poles, the width and thickness of the kidney at the level of the hill and at the level of the two poles, as well as the height and breadth of the hill, were recorded. The measurements were made comparatively right-left and in relation to 
the gender of the examined person.

\section{Results}

We found the length of the left kidney between $56.98-122.90 \mathrm{~mm}$, for female being 56.98-110.60 mm, and for male 84.73-122.90 $\mathrm{mm}$. The average length in the left kidney was $9.26 \mathrm{~cm}$, female $8.93 \mathrm{~cm}$, and male $9.59 \mathrm{~cm}$. The length of the right kidney was between 55.50 $125.0 \mathrm{~mm}$, for female being $55.50-108.40 \mathrm{~mm}$, and for male $62.04-125.0 \mathrm{~mm}$. The average kidney length was $9.42 \mathrm{~cm}$, female $9.33 \mathrm{~cm}$, and male $9.52 \mathrm{~cm}$. By comparing the length of the two kidneys, we found that in $54.55 \%$ of cases the right kidney was longer than the left one, with differences between $0.22-33.12 \mathrm{~mm}$, in $40.91 \%$ of cases the left kidney was longer than the right one with a difference of $0.61-27.62 \mathrm{~mm}$, and in $4.55 \%$ of cases the two kidneys were the same length.

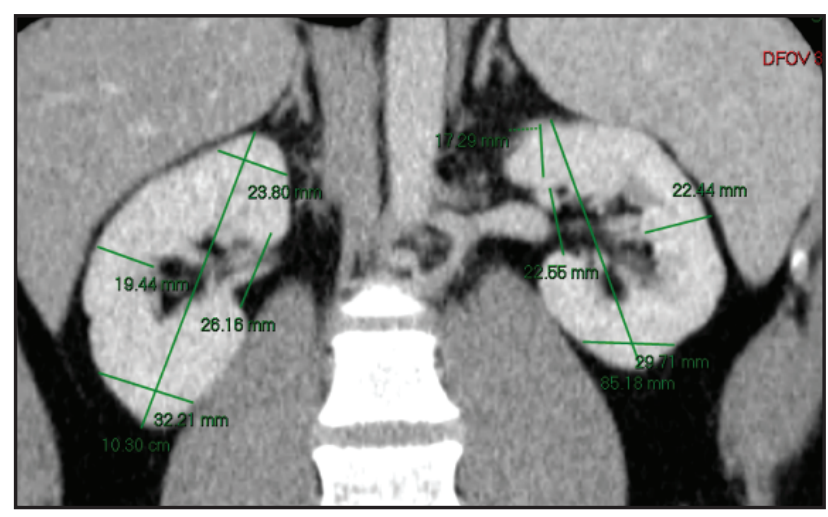

Fig. 1. Right kidney - length: $10.3 \mathrm{~cm}$; thickness: $1.94 \mathrm{~cm}$; Left kidney - length: $8.51 \mathrm{~cm}$; thickness: $2.24 \mathrm{~cm}$ (male).

In males, the right kidney was longer in $44.44 \%$ of cases, with differences of $0.22-17.82$ $\mathrm{mm}$, in $33.33 \%$ of cases the left kidney was longer than the right one with a difference of $0.61-27.62 \mathrm{~mm}$, and in $11.11 \%$ of cases the two kidneys were of the same length.

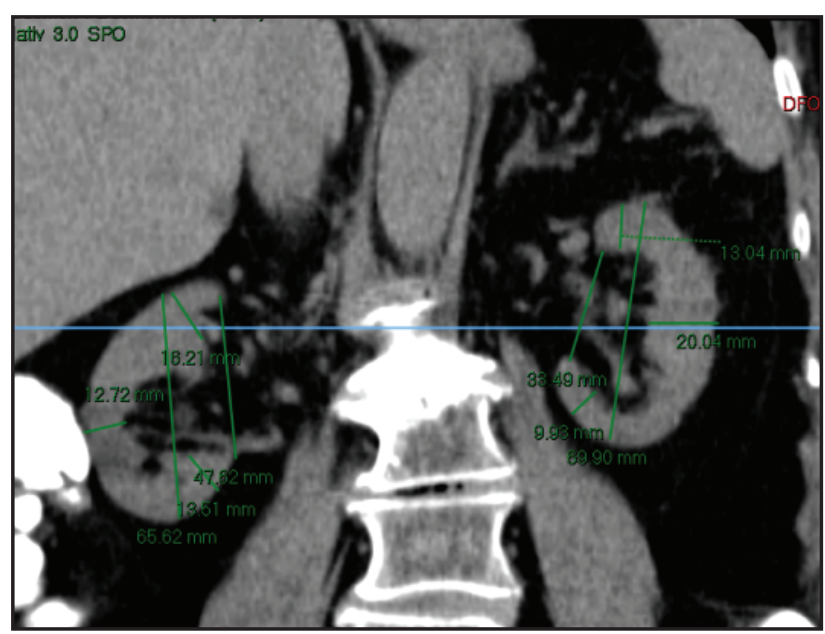

Fig. 2. Right kidney - length: 6,56 cm; thickness: $1,27 \mathrm{~cm}$; Left kidney - length: 6,99 cm; thickness: 2,0 cm (female).

In females, the right kidney was longer in $53.85 \%$ of cases, with differences of $0.48-25.95$ $\mathrm{mm}$, and in $46.15 \%$ of cases, the left kidney was longer than the right kidney, with differences $3.90-14.78 \mathrm{~mm}$.

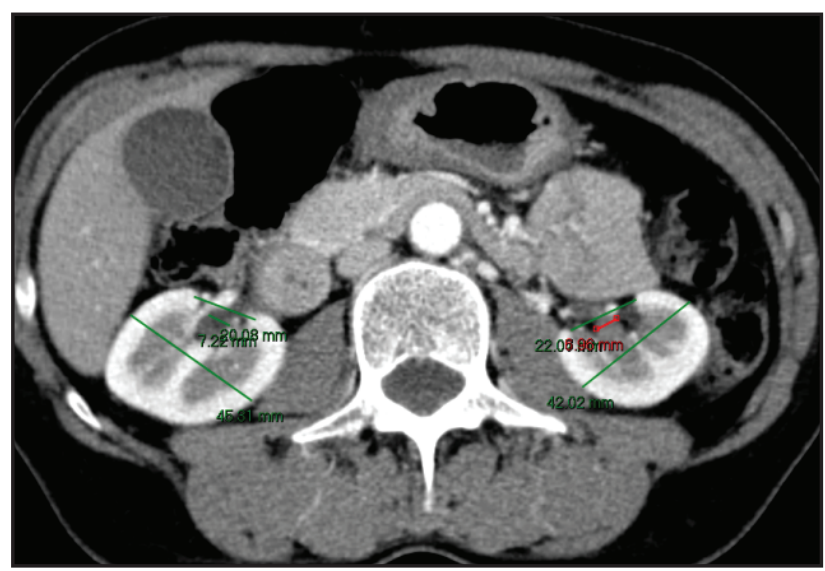

Fig. 3. Right kidney - width: $4.5 \mathrm{~cm}$; thickness: $2.0 \mathrm{~cm}$; Left kidney - width: $4.2 \mathrm{~cm}$; thickness: $2.2 \mathrm{~cm}$ (female).

The width of the left kidney in the renal hillum was found to be between $15.54-41.10 \mathrm{~mm}$, for female being between $15.54-31.0 \mathrm{~mm}$, and for male between $16.19-41.10 \mathrm{~mm}$. The average left kidney width was $5.56 \mathrm{~cm}$, female $5.82 \mathrm{~cm}$ and male $5.71 \mathrm{~cm}$. The width of the right kidney at the renal hillum was found to be between 12.72$30.90 \mathrm{~mm}$, for female being between 12.72-29.0 $\mathrm{mm}$ and for male between 14.37-30.90 $\mathrm{mm}$. The average kidney width was $5.35 \mathrm{~cm}$, for female being $5.04 \mathrm{~cm}$, and for male $5.65 \mathrm{~cm}$. 


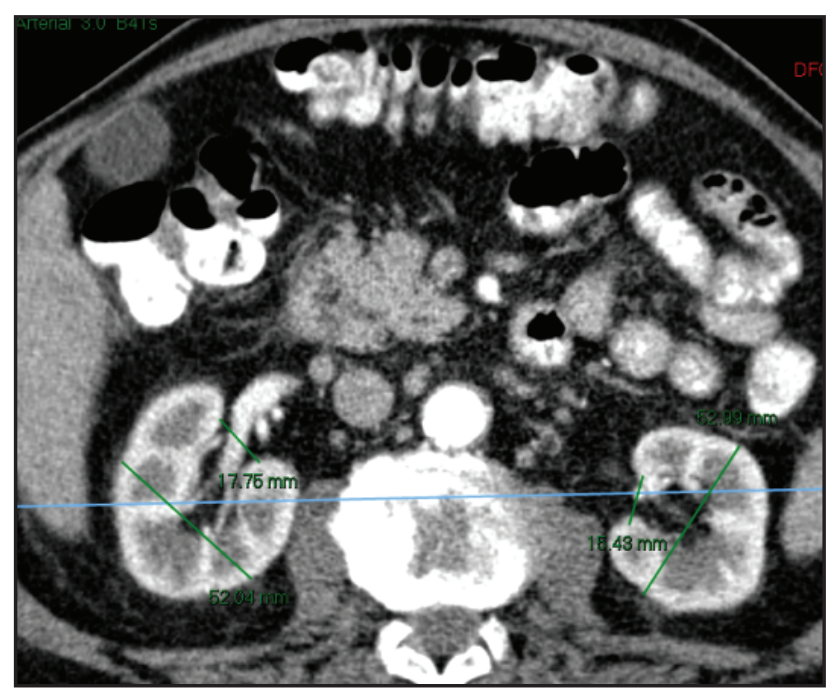

Fig. 4. Left kidney - width: $5.2 \mathrm{~cm}$; thickness: $1.77 \mathrm{~cm}$; Right kidney-height: $9.9 \mathrm{~cm}$; thickness: $2.76 \mathrm{~cm}$ (male).

Comparing the width of the two kidneys at the renal hillum, we found that in $68.18 \%$ of cases the left kidney was wider than the right kidney, with differences between $0.30-10.62 \mathrm{~mm}$, and in $31.82 \%$ of the cases the right kidney at the renal hillum was wider than the left with differences of $0.57-4.68 \mathrm{~mm}$.

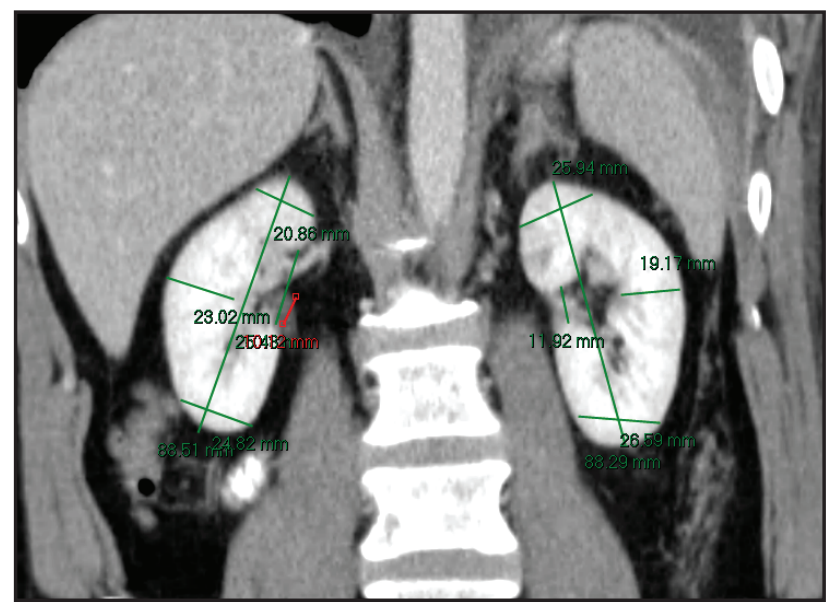

Fig.5 Right kidney - length: $8.85 \mathrm{~cm}$; thickness: 2,30 cm; Left kidney: Length: $8.82 \mathrm{~cm}$; Thickness: $1.91 \mathrm{~cm}$.

In males, the left kidney was wider than the right kidney in $55.56 \%$ of cases, with differences of $1.67-10.20 \mathrm{~mm}$, and in $44.44 \%$ of cases the right kidney was wider than the left kidney with differences of 0.57-4.68 mm.

In females, the left kidney was wider than the right kidney in $76.92 \%$ of cases, with differences of $0.30-10.62 \mathrm{~mm}$, and in $23.08 \%$ of cases, the right kidney was wider than the left, with differences of 2.29-3.71 $\mathrm{mm}$.
The thickness of the left kidney in the renal hillum was found to be between 40.0-75.80 mm, for female being $44.02-71.02 \mathrm{~mm}$, and for male between 40.0-75.80 $\mathrm{mm}$. The left kidney average thickness was $2.36 \mathrm{~cm}$, female $2.29 \mathrm{~cm}$, and male $2.42 \mathrm{~cm}$. The right kidney thickness in the renal hillum was found to be between 41.67-82.36 $\mathrm{mm}$, for female being between 41.67-60.27 mm and for male between $43.89-82.36 \mathrm{~mm}$. The right kidney average thickness was $2.28 \mathrm{~cm}$, females being $2.03 \mathrm{~cm}$, and male $2.53 \mathrm{~cm}$.

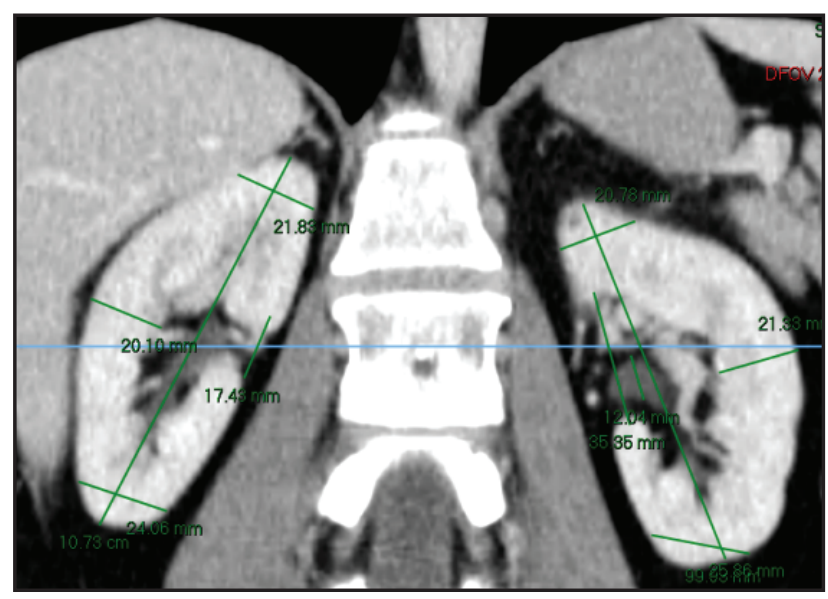

Fig. 6 Right kidney: height-107.3 mm, width in the hillum $-20.1 \mathrm{~mm}$, width at upper pole-21.83 mm, width at lower pole-24.06mm, height of the hillum-17.43mm ; Left kidney: height-99mm, width in the hillum $-21.33 \mathrm{~mm}$, upper pole width-20.78mm, lower pole width-25.86mm, height of the hillum $-35.35 \mathrm{~mm}$, renal pelvis height$12.04 \mathrm{~mm}$ (female)

Comparing the thickness of the two kidneys at the hillum level, we found that in $52.38 \%$ of the cases the left kidney was thicker than the right kidney, with differences between 0.20-19.0 $\mathrm{mm}$, and in $47.62 \%$ of the cases the right kidney was thicker than the left with differences of 0.52 $12.89 \mathrm{~mm}$.

In males, the left kidney was thicker than the right kidney in $23.81 \%$ of cases, with differences of $0.9-8.40 \mathrm{~mm}$, and in $19.05 \%$ of cases the right kidney was thicker than the left kidney with differences of 0.52-12.89 mm.

In females, the left kidney was thicker than the right kidney in $28.57 \%$ of cases, with differences of $0.20-19.0 \mathrm{~mm}$, and in $33.33 \%$ of cases, the right kidney was thicker than the left, with differences of 2.65-12.89 mm. 


\section{Discussions}

Most authors, Romanian and foreign, from the literature that we consulted, consider that the morphometry of the kidney (length, width and thickness) is a multiple of three (1-9) without specifying the differences numerically between male and female and morphometric differences between the right and left kidneys. At most, some of them mention that on male the dimensions of the kidneys are slightly larger than on female $(2,7,8,10)$ and the fact that the right kidney is more voluminous than the left one $(1,7,8,9)$, and (11) states that the left kidney is more voluminous, quoting Testut and Braus in the same sense.

Table 1 Morphometry of human, adult kidney

\begin{tabular}{|l|c|c|c|}
\hline \multicolumn{1}{|c|}{ Author } & Length $(\mathrm{cm})$ & Width $(\mathrm{cm})$ & $\begin{array}{c}\text { Thickness in } \\
\text { renal hillum } \\
(\mathrm{cm})\end{array}$ \\
\hline Rouvière & 12 & 6 & 3 \\
\hline Juskiewski & 12 & 6 & 3 \\
\hline Kamina & 12 & 6 & 3 \\
\hline Cordier & 12 & 6 & 3 \\
\hline Schünke & 12 & 6 & 3 \\
\hline Lahlaidi & 12 & 6 & 3 \\
\hline Iancu & 12 & 6 & 3 \\
\hline Chiriac & 12 & 6 & 3 \\
\hline Ulmeanu & 12 & 6 & 3 \\
\hline Papilian & 10 & $5-6$ & 3 \\
\hline Moore & 10 & 5 & 2.5 \\
\hline Gray(13) & 11 & 6 & 3 \\
\hline Beauthier $(14)$ & 11 & 6 & 3 \\
\hline Arase & $8.0-13.5$ & $4.5-7.0$ & $3.0-4.5$ \\
\hline $\begin{array}{l}\text { Panichi, } \\
\text { Bonechi }\end{array}$ & $8.9-13.5$ & $4.1-6.5$ & - \\
\hline Zăhoi & $10-12$ & $5-6$ & $3-4$ \\
\hline $\begin{array}{l}\text { Personal } \\
\text { results }\end{array}$ & $\begin{array}{c}\text { left } 5.69-12.29 \\
\text { right } 5.55-12.50\end{array}$ & $\begin{array}{l}1.55-4.11 \\
1.27-3.09\end{array}$ & $\begin{array}{c}4.40-7.10 \\
4.17-6.03\end{array}$ \\
\hline
\end{tabular}

Comparing the kidneys average length found by us and those in the literature (1-9), we found a smaller length in the left kidney by 2.74 $\mathrm{cm}$, and in the right kidney the average length found by us was smaller by $2.68 \mathrm{~mm}$. Comparing with authors who give a kidney length of less than $12 \mathrm{~cm}$, the length found by us in the left kidney was less than $(10,12)$ by $0.74 \mathrm{~cm}$ and less by $1.74 \mathrm{~cm}$ than $(13,14)$. By comparing the length found by us with that of the authors who give an interval for this, the minimum lenght in the left kidney found by us is less by $4.31 \mathrm{~cm}$ from (11), with $3.21 \mathrm{~cm}$ from (11) and smaller by $2.31 \mathrm{~cm}$ than [Arase, cited by (11)], and the minimum length of the right kidney was $4.45 \mathrm{~cm}$ lower than (11), by $2.35 \mathrm{~cm}$ than [Panichi cited by (11)] and $2.45 \mathrm{~cm}$ than [Arase, cited by (11)]. In the left kidney, the maximum length that we have found was less by $1.21 \mathrm{~cm}$ than [Arase, Panichi cited by (11)], but higher with $0.29 \mathrm{~cm}$ than (11), and to the right kidney was $0.50 \mathrm{~cm}$ bigger than (11) and $1.0 \mathrm{~cm}$ lower than [Arase, Panichi cited by (11)].

In relation to the literature $(1-9,13,14)$, we found a lower width average on the left kidney of $0.44 \mathrm{~cm}$ and on the right kidney by $0.63 \mathrm{~cm}$. In comparison to authors who gave a kidney width of less than $6 \mathrm{~cm}$ (12), the width found by us on the left kidney was $0.56 \mathrm{~cm}$ higher and on the right kidney by $1.63 \mathrm{~cm}$. By comparing the width that we found with that of the authors who gave a range for it, the minimum width of the left kidney found by us is lower by $3.45 \mathrm{~cm}$ from (11), by $2.95 \mathrm{~cm}$ from [Arase cited by (11)] and $2.55 \mathrm{~cm}$ from [Panichi cited by (11)] and the minimum width of the right kidney was lower by $3.73 \mathrm{~cm}$ than (11), $3.83 \mathrm{~cm}$ than [Panichi cited by (11)] and $2.23 \mathrm{~cm}$ compared to [Arase cited by (11)]. On the left kidney, the maximum width we found was lower by $1.89 \mathrm{~cm}$ from (11), $2.39 \mathrm{~cm}$ from [Panichi cited by (11)] and $2.89 \mathrm{~cm}$ from [Arase cited by (11)], and at right kidney was lower by $2.89 \mathrm{~cm}$ than (11), with $3.41 \mathrm{~cm}$ from [Panichi cited by (11)] and less $3.91 \mathrm{~cm}$ from [Arase cited by (11)].

In relation to the literature $(1-9,13,14)$, we found an average thickness on the left kidney lower by $1.45 \mathrm{~cm}$, and on the right kidney higher by $1.40 \mathrm{~cm}$. In relation to (12), which gives a kidney thickness of less than $3 \mathrm{~cm}$, the thickness found by us in the left kidney was $0.95 \mathrm{~cm}$ lower and in the right kidney was $1.61 \mathrm{~cm}$ higher. By comparing the thickness found by us with that of the authors who give an interval for this, the minimum thickness of the left kidney found by us is $1.45 \mathrm{~cm}$ higher than [Arase cited by (11)], and in the right kidney is lower by $1.73 \mathrm{~cm}$ from the same authors. The maximum thickness found by us in the left kidney was $3.10 \mathrm{~cm}$ higher than (11), and $2.60 \mathrm{~cm}$ than [Arase cited by (11)], and in the right kidney the thickness was $2.03 \mathrm{~cm}$ higher than (11) and $1.53 \mathrm{~cm}$ from [Arase cited by (11)]. 


\section{Conclusions}

Analyzing the morphometry in all cases, we found that the right kidney was $0.16 \mathrm{~cm}$ longer than the left kidney, the kidney width and thickness being higher in the left kidney by 0.70 $\mathrm{mm}$ and $0.77 \mathrm{~mm}$. In relation to gender, the left kidney length was higher for the males by 0.72 $\mathrm{cm}$, and for the females the right kidney was higher by $0.40 \mathrm{~mm}$. The left kidney width was higher for males by $0.11 \mathrm{~cm}$. and the right kidney width was higher for females by $0.40 \mathrm{~cm}$. The left kidney thickness was $0.28 \mathrm{~cm}$ higher for females, and for males, the right kidney thickness was 0.11 $\mathrm{cm}$ higher. Except the length and thickness of the left kidney, where the morphometric differences were 0.72 and $0.77 \mathrm{~cm}$, in the remaining cases of right / left morphometric differences and sexual differences, their values were between 0.01-0.40 $\mathrm{mm}$.

\section{References}

1. Rouvière H, Delmas A (1910-1999), Delmas V, Impr. Pollina). Voies biliaires. In: Anatomie humaine Descriptive, topographique et fonctionnelle [Internet]. Masson; 1997 [cited 2019 Feb 20]. p. 450-9. Available from: https://www.elsevier-masson.fr/anatomiehumaine-descriptive-topographique-etfonctionnelle-tronc-9782294003929.html

2. Juskiewski S GJ. Les reins et les uretères. In: Chevrel JP Anatomie Clinique Le tronc. Paris: Ed Springer-Verlag; 1994. p. 487-502.

3. Kamina P. DM V. Rein. In: In: Abdomen Appareil Digestif. Paris: Ed. Maloine; 1998. p. 83-100.

4. Cordier G.J. RCR. Anatomie du rein et de 1 uretere. Encyclopedie medico-chirurgicale. Appareil urinaire. 1-11 p.

5. Schünke M, Schulte E, Schumacher U, Voll M WK. Reins. In: Atlas d'Anatomie Prométhée Cou et organes internes. Ed. Maloine; 2005. p. 226-9.

6. Lahlaidi A. Le rein. In: Anatomie topographique Applications anatomochirurgicale de l'abdomen. Rabat: Livres Ibn Sina; 1986. p. 285-314.

7. Iancu I. Rinichii. In: Anatomie Viscere. Iasi:
Litografia IMF Iaşi; 1967. p. 363-80.

8. Chiriac M, Zamfir M ADs. Rinichii. In: Anatomia trunchiului Vol II. Iasi: UMF Iaşi; 1991. p. 249-68.

9. Ulmeanu D LT. Rinichiul. In: Anatomia sistemelor urinar şi genital. Constanta: Ed. Ex Ponto; 2002. p. 25-47.

10. Papilian V. Rinichii. In: Anatomia omului Vol 2 Splanhnologia. Bucureşti: Ed. Bic All; 1998. p. 228-43.

11. Zăhoi D, Niculescu V, Mateescu R, Mederle $\mathrm{Cl} \mathrm{CA}$. Anatomia rinichiului. In: Elemente de morfo-fiziologie renală. Timişoara: Ed. Brumar; 2000. p. 9-30.

12. Moore LK DF. Rein. In: Anatomie Médicale Aspects fondamentaux et applications cliniques. Bruxelles: Ed. De Boeck Université; 2001. p. 280.

13. Standring S. Gray's Anatomy. Kidney. In: The Anatomical Basis of Clinical Practice. Edinburg: Ed. Elsevier Churchil Livingstone; 2005. p. 1269-84.

14. Beauther JP LP. Rein. In: Traité d'Anatomie: de la théorie à la partique palpatoire Tête et tronc Propédeutique viscérale. Bruxelles: Ed. De Boeck Université; 1993. p. 348-54.

15. ******** Terminologia Anatomica. International Anatomical terminology. Ed. ThiemeStuttgart-New York, 1998, 64 